\title{
H. T. Dickinson: An Appreciation
}

\author{
Frances Dow
}

Harry Dickinson came to Edinburgh in I 966 and has made it his home ever since. Appointed initially as an Assistant Lecturer in the Department of History at the University of Edinburgh, he became Lecturer in I968 and Reader in I973. In I980 he took up the Richard Lodge Chair of British History and held it until his retirement in 2006, whereupon he became Emeritus Professor and Honorary Professorial Fellow. During his long and productive career he has published with enormous regularity: his c.v. lists items for every year since I964 and includes six singleauthored and over twenty edited volumes. He has been an effective and popular teacher at undergraduate and postgraduate levels; and he has made important contributions to the development of history in schools and universities in the UK and across the globe.

Harry's academic success is testimony, first and foremost, to his intellectual abilities and his dedicated professionalism; but it owes something, too, to the encouragement he received from key figures during his school and university years. Born in Gateshead on 9 March I939, Harry was the only one of five surviving sisters and brothers to continue his education beyond the age of sixteen: no mean achievement for a son whose parents had both left school at twelve. Happily, a teacher at Gateshead Grammar School recognised his potential and encouraged him to apply to King's College University of Durham, where he studied history from I957 until I960. He recalls being greatly impressed and influenced during his undergraduate years by the scholarly qualities he saw in J. R. Jones and Professor W. L. Burn. From Jones he learned sheer efficiency in organisation and presentation, qualities which have stayed with him throughout his career. From Burn he absorbed the importance of developing a deep appreciation of a period or topic, and his interest in the early eighteenth century was fired as a result of choosing a final year Special Subject on the reigns of William III and Anne, taught by Jones.

Jones's influence did not end there. After graduation, financial constraints led Harry to take a Diploma in Education at King's College and to become a schoolteacher. In retrospect the experience he gained then, 
and during his three years as history master at Washington Grammar School from I96I to I964, was to stand him in excellent stead as a university lecturer. But although he enjoyed teaching, he was conscious of an intellectual frustration and a desire for deeper study; this led to Jones, with whom he had kept in touch, recommending that he take an external MA, by thesis only. The thesis was to be on the War of the Spanish Succession in Spain itself, focusing on military and naval operations. In fifteen months, while studying part-time, Harry completed a 70,000 word dissertation which provided the basis for four peer-reviewed articles published in quick succession.

By the mid-I96os postgraduate opportunities and university posts were becoming more available. With support from Jones (who had moved to the University of East Anglia in I963) and Burn, Harry embarked upon a PhD. King's College Durham - which had by then become the University of Newcastle upon Tyne - awarded him the full-time Earl Grey Fellowship for I964-6. Under the supervision of W. A. Speck, he began research on 'Henry St John and the Struggle for the Leadership of the Tory Party I702-I7I4'. The thesis was completed and the degree awarded in I968, two years after his move to Edinburgh.

Harry's choice of PhD topic arose from his realisation, while exploring the War of the Spanish Succession, that the war had caused considerable debate and dissension within British domestic politics. $\mathrm{He}$ became particularly interested in the Tory criticisms of the war and chose to concentrate on Bolingbroke's role, rather than that of Harley as he had initially hoped, because he believed that Geoffrey Holmes, then the leading authority on the politics of Anne's reign, intended to write a study of Harley. Harry's work was particularly influenced by Holmes, whom he greatly admired, as well as by Speck. Although appreciative also of Lewis Namier's great work, he thought that Namier's conclusions, adopted by Robert Walcott, did not apply to Anne's reign, where party and ideological disputes were rampant.

The thesis developed into a full study of Bolingbroke's career. Published in 1970, Bolingbroke remains the standard biography to this day. In studying the later career of Bolingbroke, Harry had become interested in the political and ideological opposition to Sir Robert Walpole, in which Bolingbroke had been a leading figure. This led to a short, analytical study of Sir Robert Walpole and the Whig Supremacy (1973) and to an edited collection of primary sources, Politics and Literature in the Eighteenth Century (1974). Clearly Harry had come to the view that the Namierite approach to the politics of the eighteenth century had serious limitations. He was convinced that historians needed to study the political ideology, the political debates and the political press in the 
eighteenth century if they were to appreciate more deeply the nature of British politics of the period.

This was an important period in Harry's scholarly evolution. It resulted in the monograph on Liberty and Property: Political Ideology in Eighteenth Century Britain (I977), which he has described as the 'toughest assignment I have ever completed'. At this time intellectual historians, particularly J. G. A. Pocock and Quentin Skinner, were beginning to explore lesser-known philosophical works in an effort to understand the intellectual climate of early modern Britain. Harry's work, however, was focused more on linking political pamphlets and polemical literature, which often lacked philosophical depth, with the practical political issues of the day. While a few other scholars, such as J. P. Kenyon and John Brewer, were attempting this for short periods of British history, Harry's work offered an interpretation of British politics throughout the whole eighteenth century. Essentially, it related the ideological issues discussed in the political press with the major political divisions in national politics and was an explicit challenge to the Namierite approach to eighteenth-century British politics. Since then, no historian has been satisfied with the Namierite approach alone or willing to dismiss the importance of the press and the ideological debates of the period.

Harry's interest in political ideas, ideology and action was to find further expression in later publications, notably British Radicalism and the French Revolution (I985). Although much of his later work has been concerned with the 'age of revolution' of the later eighteenth century, after Liberty and Property his interest in politics across the whole eighteenth century did not wane. Increasingly, however, his concern was with the political world beyond the confines of the aristocratic or Westminster elites as he sought to develop an understanding of how elite and popular politics, as well as practical politics and political debates, interacted with one another. One of the major fruits of this was The Politics of the People in Eighteenth-Century Britain (1995).

From any brief survey of Harry's published work, certain things stand out which say much about the man as well as the scholar. Harry has tended to concentrate on big issues and long periods. His intellectual tendency has been to emphasise similarities and to establish relationships between people, ideas and actions, rather than to emphasise differences and to highlight incoherencies. To adopt the terminology used in the debate between J. H. Hexter and Christopher Hill in I975, though without its pejorative connotations, Harry is much more of a 'lumper' than a 'splitter'. He has tried to build up an original synthesis about topics that have interested him, rather than concentrate on deep, forensic investigation of a very narrow or specific topic. Thus by 
doing justice to both Walpole and Bolingbroke, by exploring practical politics and political ideas, by linking elite with popular politics and by looking at radical and conservative responses in Britain to both the American and French Revolutions, he has produced new interpretations and insights into some of the major issues in eighteenth-century British politics.

Harry's scholarly excellence has led to many prestigious awards, fellowships and appointments. He was awarded the degree of DLitt by the University of Edinburgh in 1986 and was elected Fellow of the Royal Society of Edinburgh in 1998. He has been invited to deliver prestigious lectures, including the Anstey Memorial Lectures at the University of Kent (I987) and The History of Parliament Annual Lecture (2010). Throughout his career he has held numerous research fellowships, including several which have enabled him to work in major libraries in the United States: Fulbright Fellow, Huntington Library Fellow and Folger Shakespeare Library Senior Fellow, all in I973; Ahmanson Foundation Fellow, Clark Library, UCLA, I987; and Lewis Walpole Library Fellow at Yale University, 2004. An honour he particularly appreciated was appointment as Douglas Southall Freeman Visiting Professor at the University of Richmond, Virginia in 1997.

Harry's work has been published in fourteen countries and translated into seven languages. It comes as no surprise therefore that he has received dozens of invitations to speak at international conferences and to make academic visits for both research and teaching purposes within Britain and in many countries in North America, Europe and Asia. All academics welcome such invitations as evidence of peer esteem; but as an instinctive teacher and avid learner Harry especially valued those occasions which offered an opportunity for extended dialogue with both junior and senior scholars. For him, research is in the broadest sense a collaborative and cooperative enterprise in which all parties can learn from one another, whatever their position in the academic 'pecking order'.

One such contact, which blossomed into a fruitful exchange with the Ludwig Maximilian University of Munich, Germany, began through his association with Professor Eckhart Hellmuth. In I 997 the British Council gave him funding to develop research links in British history with postgraduates and staff in LMU. The focus was to be on the history of ideas in their cultural and political context during the long eighteenth century. Over the next four years small teams of faculty members and postgraduate students made week-long organised visits to one another's universities for seminars, discussion of student research projects, advice sessions and visits to museums and galleries. Harry maintained the 
connection with Munich, delivering Hauptseminars and giving research papers in later years. Another academic link, which was focused more strongly on teaching, was cemented with Dr Pascal Dupuy at the University of Rouen, France. For several years from 2002 Harry taught an intensive two-week course in Rouen on Britain in the period of the French Revolution to a group which included Masters students. Other links, with Poland and above all with China, were to achieve even greater significance, as we shall see below.

Working with postgraduate students is an aspect of Harry's career at the University of Edinburgh which he has much enjoyed, and for which he has gained an enviable reputation. He has been the formal supervisor of over thirty successful doctoral students and has given specific help and advice to countless others. He has also supervised many dissertations at Masters level, where a number of students (like Harry himself) have gained their first postgraduate degree by thesis only. The list of contributors to the present volume testifies to the excellence of several of his former doctoral students, and others who could not be included have also gone on to successful careers in universities across the globe.

His doctoral students have come from a range of countries, including Canada, China, France, Germany, Japan, Norway, Taiwan and the United States of America as well as all parts of the United Kingdom. He has felt a special obligation to help students from educational systems which differ from that in Britain, most particularly those whose first language is not English. In addition to his readiness to advise on methods and sources, he has devoted much time to discussing problems of structure and organisation in the writing of a thesis, and to helping his supervisees develop a clear writing style. His patience in this regard with international students is legendary. It is noteworthy that of the administrative roles which Harry has filled at the University of Edinburgh, two were concerned with postgraduate affairs. As Associate Dean Postgraduate in what was then the Faculty of Arts he played a major role in introducing the degree of MSc by Research; and as Convener of the Senatus Postgraduate Studies Committee from I 998 to 200 I he chaired the senior committee dealing with postgraduate affairs across the whole university.

Despite his interest in postgraduate matters, Harry never neglected undergraduate teaching. He always undertook a full teaching load and was a particularly effective lecturer to large classes, where his structured approach, clarity of presentation and sheer efficiency in covering the essential features of a historical problem gained the admiration of students of all educational backgrounds and abilities. His training as 
a schoolteacher undoubtedly benefited him as a lecturer and tutor, but so too did his memory of how much he, as a first-generation university student from a working-class family, had owed to the helpfulness of his teachers at King's College Durham. J. R. Jones and W. L. Burn had been scholarly role models, but it was a part-time lecturer, Mrs Elizabeth Fawcett, who had taken great pains to advise him on the techniques of writing essays and developing a prose style. Thereafter Harry always tried to offer similar help to students who most needed it. A belief in the responsibility of established academics to advance their discipline, encourage younger scholars and improve the quality of teaching and learning underpins another aspect of Harry's career, his distinguished service to the wider scholarly community in the UK. He was a Vice President of the Royal Historical Society from I99I to I995 and again from 2003 to 2007; he served on the history panel for the Research Assessment Exercise of I992; and he has had a long association with the Arts and Humanities Research Council and its predecessor the Arts and Humanities Research Board. From 2002 to 2006 he chaired the history panel of the AHRB (which became a Research Council in April 2005), and was later involved with the AHRC's development of block grant schemes for postgraduate scholarships. Currently he is a member of the AHRC's Peer Review College.

Over many years Harry has been involved with various bodies set up across the UK to monitor standards and quality in teaching and learning in higher education. From I987 to I993 he worked with the Council for National Academic Awards, which validated degreelevel programmes in those higher education institutions that had not yet achieved full university status. The later I990s saw him acting as an academic reviewer with the Higher Education Quality Council. Two other appointments were particularly to his liking, because they focused directly on the teaching of history. From I 995 to I996 he was appointed by the Scottish Funding Council as a team leader on its Teaching Quality Assessment Panel in history. This involved visits to several of Scotland's universities, where the lessons that could be learned from observing how others went about the teaching of history were of genuine interest to him. History Benchmarking was another challenge he enjoyed, following appointment to the UK-wide Quality Assurance Agency in 1998, because it involved consultation across the profession about the knowledge and skills required for a history degree. On a more personal level, Harry's commitment to reflecting on and improving his own teaching brought him membership of the Institute of Learning and Teaching in 2000; this later became a Fellowship of the Higher Education Academy. 
Harry's interest in developing the curriculum and improving the standards of teaching in history was not confined to higher education. He was equally concerned with the study of history in schools, which he rightly saw as an indispensable foundation for the health of the subject in universities. His most notable contribution to history outside the academy came through his membership of the Historical Association, which he first joined as an undergraduate. The Association's broad aims - to further the study, teaching and enjoyment of history at all levels - reflected his own experience and outlook. He became a Council member in I982, was Vice President from I995 to I996, Deputy President from I996 to I998 and then from 2002 to 2005 President. During these years the breadth of his commitment to history was shown in his willingness to give talks to many schools and local societies, as well as in his editorship from I993 to 2000 of the Association's academic journal History. In order to bring to fruition plans which had been mooted during his presidency, he was re-appointed Vice President in 2005. He successfully promoted the Association's request to the Privy Council for a Royal Charter, which enabled it to award fellowships not only to those historians with distinguished publication records, but also to those who had advanced good practice in teaching and assessment in schools, and to others who had disseminated a love of history to the wider public.

Harry's expertise in assessing the quality of research and teaching and his commitment to the advancement of historical study was to find its fullest and most significant expression outside the UK. In 2003 his academic reputation brought an invitation to lead a team of international experts to assess the quality of research being undertaken in history and archaeology in two universities and three research institutes in Tartu and Tallinn, Estonia. A second visit a year later assessed the quality of undergraduate teaching in the three institutions in Tallinn. The team's recommendation that these bodies should unite into a new University of Tallinn was accepted, and in 2006 a team, again led by Harry, returned to Tallinn to evaluate degree provision in the new university. A more extensive visit to Tartu and Tallinn followed in 2008 .

When Harry retired from his full-time position as Richard Lodge Professor in 2006, the Senate of the University of Edinburgh recorded in a Special Minute that 'without doubt ... Professor Dickinson's main passion has been to advance the teaching of British history throughout the world'. The most impressive examples of this have been the relations he has built up with Poland and, above all, with China.

The connection with Poland came about when he was contacted by a young Polish scholar studying at the Institute for Advanced 
Studies in the Humanities at Edinburgh. Dr Pawel Hanczewski from the Nicolas Copernicus University of Torun, Poland was on a shortterm fellowship at the Institute in the summer of $200 \mathrm{I}$ and was keen to seek advice on developing the study of British history at his home university. Harry was particularly sympathetic to Dr Hanczewski's wish to promote historical study in an environment where there was limited autonomy for the individual scholar and inadequate resources for curriculum innovation or for research materials. There began a long-lasting exchange between the two on all matters related to research and teaching, with Harry on occasion also proffering advice to other colleagues of Dr Hanczewski and to graduate students. Most importantly, since 2003 he has made annual weeklong visits to Torun to teach intensive courses on eighteenth-century British history. He has given lectures and seminars on aspects of Britain in the age of the American and French Revolutions, devoting many hours to formal teaching and to informal discussion.

Undoubtedly the most sustained and significant expression of Harry's commitment to promoting British history worldwide has been his connection with China. It is no exaggeration to say that it is largely thanks to him that British historical studies now flourish in China. The link goes back to 1978 when, after a chance encounter with an Edinburgh alumnus, Professor Wang Juefei of Nanjing University wrote to Harry to ask for his help in reviving the study of British history. After the devastating effects of the Cultural Revolution of I966-76, the priorities were to educate young scholars who could fill the shortage of university teachers and to replace resources, particularly books and journals, which had been lost or destroyed. Harry's response was twofold. In I980, with the aid of a Winston Churchill Memorial Trust Travelling Fellowship, he accepted Professor Wang's invitation to give extended courses of lectures in Nanjing to about forty young Chinese scholars, drawn from universities from all parts of China. He went again in I 983 . Several of these scholars now occupy leading academic positions across China, notably in Peking University. Harry was also assiduous in writing to publishers in Britain and elsewhere to ask them to donate books to Nanjing University, with considerable success. The British Council was also supportive. Professor Wang meanwhile organised the China-British History Association to coordinate the improvement in British studies across China. He himself made two lengthy visits to Britain in the early I980s. In this way, networks were built up which drew in historians from other British universities and laid the foundation for Chinese scholars to visit the UK to work in libraries and archives. 
An important milestone was reached in 1987 when Harry and Wang Juefei collaborated on the first international conference on British history to be held in China for many decades. For this, Harry secured funding from Cable and Wireless plc, which had business interests in China. He persuaded over twenty western experts from Britain, the USA, France and Germany to give papers to an audience which included over one hundred scholars from China's leading universities, among them delegates from Beijing, Wuhan, Shanghai, Tianjin and Nanjing. Many of the western experts forged lasting personal connections with their Chinese counterparts which facilitated later exchanges and collaborations. It was a fitting recognition of the part that Harry had played in these developments that in 1987 he was made (and remains) Concurrent Professor of History at Nanjing University, an honorary appointment which enabled him formally to supervise Nanjing students.

For some years thereafter the political climate was not conducive to putting British-Chinese links on a firmer, more institutional, footing. It was not until the end of the r 990 s and, in many cases, even later that UK universities began seriously to engage with China. Harry's commitment to the development of British studies in China was nonetheless unwavering and earned him the gratitude and trust of his Chinese colleagues. Although he made only one academic visit in the I990s, to Nanjing in I994, he continued to offer what help he could to individual scholars and, often at considerable personal expense, sent books and other materials to assist their research. As funding became more available, Harry, with characteristic energy and determination, advanced the case for British history. Together with like-minded historians in other universities he secured opportunities for a succession of Chinese postgraduate students and postdoctoral workers to come to Britain.

Since 2004 Harry has made visits to China in every year except one, teaching at a total of twelve universities in nine different cities. His most frequent visits have been to Peking University and Capital Normal University in Beijing. On three occasions he has attended the multidisciplinary and highly prestigious Beijing Forum, delivering a keynote speech in 2008 and a special address in 2013 to mark the tenth anniversary of the Forum. This signal honour gave him great pleasure. So too did the graduation in 20I4 of one of his Edinburgh doctoral students, the son of a young Chinese graduate (now a Professor) whom he had taught in Nanjing in the I980s.

It is fitting to conclude this appreciation of Harry Dickinson's career with an account of his contribution to the study of British history in 
China. Although there are many other arenas in which he has excelled as a scholar and teacher, this is undeniably the one in which his personal qualities and academic abilities have made the most difference. It is also, by his own admission, the achievement of which he is most proud and from which he has gained the most personal satisfaction. 